\title{
STUDENTS` ENTREPRENEURIAL BEHAVIOR IN THE APPLICATION OF 'EKRENFATIHA' PRODUCTIVE ENTREPRENEURIAL TEACHING MODEL AT CULINARY PROGRAMS OF VOCATIONAL SCHOOLS
}

\author{
${ }^{1}$ Badraningsih Lastariwati; ${ }^{2}$ Pardjono; ${ }^{3}$ Sukamto \\ ${ }^{1,2,3}$ Yogyakarta State University \\ badraningsih@yahoo.co.id; ${ }^{1}$ jpardjono@yahoo.com; ${ }^{3}$ otmakus2010@yahoo.co.id
}

\begin{abstract}
The purpose of the study is to observe students' entrepreneurial behaviors in the implementation of entrepreneurship processes in production subjects. The study applied production entrepreneurial teaching model to some vocational high school students with their 'EkRenFaTiHa Catering' as their project. The entrepreneur process was integrated in the catering production subject and it consisted of the following aspects: Exploration, business plans, facilitation, action and output. The study employed research and development approach, which referred to Plomp development model. The data were analyzed by using descriptive statistics. The research subjects were some students of 1 Sewon State Vocational High School. The results of the test on the model implementation show the students' mastery of the entrepreneurial behaviors showing the characteristics of responsibility, innovation, honesty, independence, creativity, leadership, dilligence, discipline, cooperation, risk-taking and good communication. It also shows that there is a concrete improvement during the continuous process regarding every observed entrepreneurial behavior, and in general the students' entrepreneurial behaviors could be classified as good.
\end{abstract}

Keywords: entrepreneurial behavior, productive entrepreneurial learning

How to cite item:

Lastariwati, B., Pardjono, P., \& Sukamto, S. (2016). Students' entrepreneurial behavior in the application of 'EkRenFaTiHa' productive entrepreneurial teaching model at culinary programs vocational schools. Research and Evaluation in Education, 2(1), 53-70. doi: http://dx.doi.org/10.21831/reid.v2i1.6528 


\section{Introduction}

One of the educational challenges in Indonesia is improvement in both vocational quantity and quality in order to meet local and national demands and to be able to compete globally. In addition, there is also an expectation that education in Indonesia should produce creative human resources to develop creative economy and to design an effective vocational education for all vocational high schools or other vocational institutions. The reason is that vocational high school students are very close to employment, and one of the available employements is entrepreneurship. As a result, entrepreneurship might become one of their career options (European Commission Enterprise and Industry (ECEI), 2009, p.35).

Being entrepreneurs might decrease the number of unemployment that has been one of the urgent matters happening nowadays in Indonesia. Furthermore, it is also useful in terms of increasing visa and prosperity of the country. It might also be useful for decreasing the level of poverty (Macke \& Markey, 2003, p.1). It shows that entrepreneurship might be the best potential for economy and development. Through the development of creative economy, the government expects that entrepreneurship culture will be a part of Indonesian working ethics in order to generate reliable, tough and indepent entrepreneurs. The expectation is very important because entrepreneurial activities belong not only to the micro-economy setting but also to the macro-economy (Centre of Curriculum of the Ministry of National Education, 2010).

Vocational education provides not only skills but also other relevant knowledge in order to get a proper living. The function of vocational high schools in preparing the needs of necessary labor covers two dimensions. The first is the quantitative dimension related to the educational function of vocational school to supply educated and skillful labors according to the demands of the employment. The second is the qualitative dimension to generate educated, trained and skillful labors who can be the motors of regional economic movement (Directorate General of Secondary
Education, 2011, p.73). In relation to these statements, vocational education is identical with learning to work. Vocational education tries to improve one's technique and position in his or her environment through technology mastery and, at the same time, to meet the needs of employment. As a result, vocational education is often regarded as having strong contribution to the national economy.

The development of creative economy in 2010-2014 was based on the individual creativity, skills and talents in order to pursuit economic creative ideas that will have great impacts on Indonesian prosperity (Directorate General of Secondary Education, 2011, p.54). Education in Indonesia is oriented toward habituation, empowerment and formation to bring about noble, honest and superior characteristics altogether with the other life skills. The paradigm treats, facilitates and encourages students to be independent subjects with responsibility, creativity, innovation, support and entrepreneurship (Ministry of Education and Culture, 2012, p.6; Ministry of Education and Culture, 2012, p.2).

Entrepreneurship in Indonesia is still relatively behind other countries although it has entered the age of knowledge and information. Based on a calculation provided by Ciputra Foundation, the number of entrepreneurs in Indonesia is 400,000 people (around $0.18 \%$ of total population) (Ciputra, 2009, November 3). It is below the world's standard figure. According to Ciputra (2009, November 3) and Moerdiyanto (2013, p.7), a country will be developed if the number of entrepreneurs is more than $2 \%$ of the total population. In order to improve the situation, the government should take some serious efforts and one of them is trying to achieve demographic dividend. The demographic dividend is predicted to be achieved in 2020-2035 (Ministry of Education and Culture, 2012, p.12). In order to take the best of it, starting from 2010-2035, Indonesia should have big investment on the human resources development, by establishing a universal secondary education, and entrepreneurship should be one of the components in it. (Ministry of Education and Culture, 2012, p.1). As mandated in Act of the Republic of Indonesia 
(2003) Number 20 Year 2003 about the national education system, the National Long Term Development Plan of the Ministry of Education National Year 2010-2014 (Ministry of National Education, 2010, pp.1-2) emphasizes that the efforts to pursue the human resources quality include: Science, technology, and economic competitive edge. Therefore, through entrepreneurial learning, students will be able to achieve the targeted number of entrepreneurs in Indonesia.

Entrepreneurship-based education is an education that implements the principles and methodologies of value internalization to the students. It might be pursued through a curriculum integrated to the development occurring around the students' neighborhood and through the use of teaching models and strategies that is relevant to the teaching objectives (Winarno, 2008, p.124). Badan Nasional Sertifikasi Profesi (BNSP) or National Professional Certification Agency states that the entrepreneurship education might generate entrepreneurial behaviors and leardership characteristics which are very related to the ways of managing business so that students will be able to start their own business independently (BNSP, 2006). The objective of entrepreneurship programs in vocational high schools is basically to internalize entrepreneurial values through entrepreneurial habituation.

According to the European Commission Enterprise and Industry (ECEI) (2009), entrepreneurial paradigm and skills might be promoted through learning by doing (experiencing entrepreneurship in real practice). Therefore, entrepreneurship is expected to be the life attitude and national character of Indonesian people (Ciputra, 2009, November 3). Furthermore, entrepreneurial education is one of the best ways for supporting economic growth and creating more employment. The idea is in accordance with the results of the latest research saying that $78 \%$ of the graduates from entrepreneurial education are able to work right upon graduation (Directorate General for Enterprise \& Industry of European Commission, 2012, p.4).

Nowadays, entrepreneurial learning in vocational high schools is one of the supporting theoretical training and education subjects.
The implementation of entrepreneurship in vocational high schools recently is around $1.93 \%$ of the total periods for six semesters. It is insufficient to create independence and entrepreneurship spirit for the graduates. Therefore, the design of entrepreneurial learning in vocational high schools should be reviewed on the following aspects: Curriculum, learning strategy, learning method, media and teaching media (Sarbiran, 2002). In order to improve the effectiveness of entrepreneurial encouragement to the students, there should be a model development for the production entrepreneurial learning in the culinary vocational high schools. Thus, this research is focused on the entrepreneurial education in culinary vocational high schools.

The integration of entrepreneurial stages and culinary production training in education subjects is based on the nested approach with project-based learning. As a result, the students will be able to implement the entrepreneurial skills in real practice within their respective domain and to study several production skills altogether at the same time. Thereby, the teachers will be able to strengthen the entrepreneurial values, attitudes, and behaviors of the students. The objective of the research, then, is to develop entrepreneurial behaviors by implementing entrepreneurship processes in the production subjects. This research observes the implementation of entrepreneurship encouragement through a teaching model which is called 'EkRenFaTiHa' for the productive entrepreneurship subjects.

Entrepreneurship is a value that should be actualized into behaviors that will be the source of energy, motor, objective, strategy, effort, process and business (Sanusi, 1994). According to Prawiro in the Centre of Curriculum, the Ministry of National Education (2010, p.16), entrepreneurship is a necessary value for starting and developing a business. Entrepreneurship is a process of creating something new (being creative) and different (being innovative) which will provide benefits for the competitive edge. A similar understanding is given by Kuratko and Hodgetts (1989, pp.5-6) and also Hisrich and Peters (2002, p.42). They argue that entrepreneur- 
ship is a process of innovation and creation. Entrepreneurship is a process of implementing creativity and innovation in solving problems and finding solutions for improving business opportunities (Zimmerer, 1996, p.20). Entrepreneurship refers to the values that form one's characters and behaviors in order to stay creative, empowered, noble and humble so that he or she will be able to improve his or her income within his or her business activities (Centre of Curriculum of Ministry of National Education, 2010, p.15). Based on these definitions, it can be concluded that entrepreneurship is a process of implementing the values that form one's characters and behaviors that will be able to grow creativity and innovation in solving problems and in finding opportunities.

Kuratko and Hodgetts (1989, p.6) explain that people who perform entrepreneurship are called entrepreneurs. Entrepreneurs are motivators as well as creators (Kao, 1991, p.191). Entrepreneurs also refer to individuals with strong, creative, and innovative edge, who master in-depth business knowledge and who behave under the objective of creating a new business unit (Suryana, 2003, p.10).

Meredith in Pusposutardjo (1999), provides the characteristics of an entrepreneur. She writes that the characteristics of an entrepreneur are: (a) Having self-confidence; (b) having orientation toward task and output; (c) having willing to take risk; (d) having leadership; (e) having future orientation; and (f) having originality. From the behavioral perspective, psychiatricts regard an entrepreneur as an achievement-oriented individual who has been stimulated to find new challenges and output. Meanwhile, Vesper (in Winardi, 2004) in a very positive tone toward the market economy regards entrepreneurs as the pillar of industry, and the motor and pioneer who constructively destroy the condition of 'Status Quo'. As stated by Muhadi and Saptono (2005, p.15), that there are several factors which strongly influence students' entrepreneurship spirit, such as: The parents' employment background, the families' cultures, and the training and education process at school. Furthermore, the entrepreneurship spirit consists of two factors, namely, personal values and orientation. Personal values are the traits that consist of locus of internal control, creativity, independence and planning. Orientation consists of aspects of achievement pursuit and moderate real risk-taking ability (Noer \& Wirjodirjo, 2007, p.237). Locus of internal control is the core of entrepreneurship spirit (Purnomo, 1999).

The entrepreneurship spirit covers the following aspects: Independent attitude and paradigm, willingness to take a risk, responsibility, always creating and improving the resources value, openness for feedbacks, always looking for better chances, not getting satisfied easily, always performing innovation and improvisation for future improvement, and having a good moral responsibility (Suryana, 2003, p.10). The entrepreneurship spirit encourages someone to be interested in finding and managing business professionally. The interest is accompanied by an accurate planning and calculation. Kashmir (2007, p.17) states that entrepreneurship tries to find benefit and create profitable business opportunities. Suffering loss is not a big problem since entrepreneurs are aware that loss is a natural consequence. They even believe the bigger the risk, the bigger profit they will get. In their opinion, they would not suffer any loss as long as they work with full of encouragement and calculation. The mastery of entrepreneurship spirit is expected to combine motivation, vision, optimism, and communication and courage in utilizing the business opportunity (Suryana, 2003, p.13). According to Kuehl and Lambing (1999, p.11), entrepreneurship is a creative business that establishes values from nothing which will be useful for everyone. Furthermore, they state that successful entrepreneurship has four main elements, namely: (1) Ability (related to skills and IQ) in reading opportunities, innovations, management and sale; (2) encouragement (related to EQ and mental) in coping with fear, risk control and leaving 'comfort zone'; (3) determination (related to self-motivation) in the form of persistence, firmness and mind power; and (4) creativity that 'generates' inspirations for the ideas. Ideas are used for finding opportunities based on the intuition he or she gets (related to the experience). 
On the other hand, the Directorate General of Educational Quality Improvement and Education Personnel (2010, pp.9-12) suggests that there are two types of entrepreneurship dimensions or characteristics, namely: (a) The fundamental quality, covering mindset, heartset and physical strength; and (b) instrumental quality, which covers interdiscipline mastery. Therefore, it can be concluded that the fundamental quality of entrepreneurship, which covers mindset, heartset and physical strength, is very essential in an entrepreneurial process. The reason is that in an entrepreneurial process, an entrepreneur needs a mindset for establishing creative and innovative ideas. He or she also needs some mentality for building integrated, smart, dynamic, harmonious and flexible teamwork so that he or she might be self-confident and competitive on the basis of high solidarity. All of these aspects should be supported by good physical strength.

Such an entrepreneurial process involves more than the division of management position. According to Hisrich, Peters, and Dean (2005, p.39), an entrepreneurial process has the following four different stages: (a) Opportunity identification and evaluation; (b) business plan development; (c) decisions on necessary resources; and (d) output management. Similarly, a review on the entrepreneurial process has also been provided by Ciputra. In Ciputra University, an entrepreneurial process has the following five stages: Discovery, concept developent, resources, action and harvesting. The five stages are implemented according to the National Content Standards for the Entrepreneurship Education. These five stages, altogether with individual characters and entrepreneurial behaviors, become an entity in the entrepreneurship skills (Consortium for Entrepreneurship Education, 2004, appendices). According to the Consortium for Entrepreneurship Education (2004), an entrepreneurial process should go through the following stages: Discovery (8 aspects), concept development (8 aspects), resourcing (7 aspects), actualization (11 aspects) and harvesting (4 aspects). In order to have better understanding of the stages of an entrepreneurial process in the productive entrepre- neurship learning model for the vocational high schools, these following terms are used: Exploration, business plan, facilitation, action and output.

\section{Exploration}

Exploration is the stage of performing a creative and innovative mindset. A creative mindset is demanded for describing the future business situation and operation. It will also help in providing vision that might not be made by an exploration toward a trend in the present time. The exploration stage covers the following aspects: Exploration toward expectation and inspiration, idea establishment, and creative and innovative idea development.

\section{Business Plan}

A business plan is a stage of designing the creation, distribution, and transformation from the value proportion to the selected customer segmentation through several activities facilitated by the resources with an objective of generating profits (Osterwalder \& Pigneur, 2010). A business plan covers every single aspect that an entrepreneur would like to perform with his or her business and how they might be implemented. The process of composing the aspects that will be involved in realizing the business ideas demands an understanding of what, why, who, how, where, when and how much the entrepreneurial efforts might be made. Such a process urges the entrepreneurs to take decision and have wider sight on the ideas and on how to turn these ideas into a business. This stage also helps them to consider the areas that need more reviews (Ehmke \& Akridge, 2005, p.1). The business mind stage covers the following aspects: Decision on market targets, product type, product superiority, risk and opportunity, marketing strategy, capital source, and promotion strategy.

\section{Facilitation}

The facilitation stage covers natural resources management, human resources management, space management, capital management, raw materials management, decision on production process, and decision on 
cost demands. According to Soegoto (2010, p.199), human resources management is a series of organizational activities directed toward recruiting, developing and maintaining the existing employees in order to achieve the company's objectives.

Action

Action means transforming business ideas into reality. In the implementation, the role of an entrepreneur as the leader of a company strongly determines the business success. This stage consists of employee motivation, supervision, direction and coordination.

Evaluation

This stage is also known as evaluation because all of the output will be evaluated by companies. Basically, the evaluation is focused on the comparison between the planning and implementation. If there is a divergence, it would be evaluated. The output stage covers evaluation and reflection.

Entrepreneurship is the intertwine of overall vocational education and entrepreneurial attitudes maintained through the overall vocational education system (ECEI, 2009, p.22). Apart from the existing vocational domains, ECEI (2009, p.7) states that the most effective way in teaching entrepreneurship is to have the students participated in practical projects and other learning activities emphasized on 'learning-by-doing' principle. Therefore, they will have actual experience. The problem-based and experience-oriented education has very important role in developing the entrepreneurial mindset and ability.

The efforts to introduce entrepreneurship as an explicit objective in a curriculum will become a clear signal that entrepreneurship is important for every student. In addition, entrepreneurship will ease the teachers to spend the teaching periods on the given subjects because entrepreneurship is not explicitly included in the curriculum. Moreover, there have been many occasions in which the teachers would like to participate with the students in the entrepreneurial activities but they have to prepare these activities outside the periods. The learning type should refer to the curriculum available to all students and should not depend on individual expectation, or the initiatives of the teachers and the school. Several experts recommend entrepreneurship to be introduced as a compulsory item in the curriculum so that all students would be able to learn it (ECEI, 2009, p.23).

Entrepreneurship education is not intended to be limited to the general business or economy study because it is aimed at increasing creativity, innovation, and entrepreneurial efforts. In some cases, it is integrated into the compulsory curriculum; but in some others, it is an optional subject or extracurricular activity provided by the schools (ECEI, 2009, p.23). Higher education should increase students' awareness on entrepreneurship. The entrepreneurial mindset and skills might be well promoted through the principle of 'learning-by-doing' and practical entrepreneurial experiences (projects and practical activities) (Commission of the European Communities, 2006, p.4).

The learning model implemented in the study was project-based learning. Projectbased learning is an approach demanding students to construct a 'bridge' connecting learning materials of multiple subjects. By doing so, they will be able to view the knowledge holistically. Project-based learning is an indepth investigation on a topic in the real world; it will be valuable for the students' attention and efforts.

Project-based learning is an approach that pays attention to comprehension. The students explore, interprete and synthesize information in meaningful manner. Global School Net (2000) reported the results of a study by the Auto Desk Foundation regarding the characteristics of project-based learning. It showed that project-based learning was an approach possessing the following characteristics: Students made decision on the framework; they proposed some problems or challenges; they designed a process to find the solution to overcome the proposed problems or challenges; they were collaboratively responsible for accessing and managing information to solve the problems; the evaluation process was implemented continuously; the 
students periodically performed reflections on the activities they had performed; the final product of learning activities would be evaluated qualitatively; and the learning situation was very tolerant to mistakes and changes.

The project-based learning approach was developed based on the philosophy of learning constructivism. Constructivism develops a learning atmosphere that urges the students to arrange their own knowledge (Bell, 1995, p.28). The project-based learning provides freedom for the students to plan the learning activities, to implement a project collaboratively and to generate product that might be presented to other people.

\section{Entrepreneurial Behaviors}

Entrepreneurial characters, attitudes, spirit and values might appear in the form of entrepreneurial behaviors (Suryana, 2003, p.6). Behavior is a function of direct interaction between an individual and his or her orientation toward objectives. Thus, behaviors are motivated by the desire to achieve certain objectives (Winardi, 2004, p.32). According to Bird and Schjoedt (2009), behaviors are action. Therefore, entrepreneurial behaviors describe behaviors as individual activities (businessmen).

On the other hand, entrepreneurial behaviors are reflected in attitudes, interpersonal relationship, arrangement capabilities, marketing and finance (Hawkins \& Turla, 1993, p.388). Lumpkin, Cogliser, and Schneider (2009, p.50) and also Wiklund and Shepherd (2003, p.1310) believe entrepreneurial behaviors as individual behaviors instead of company behaviors. Entrepreneurial behaviors are proximal results of business actor's cognition and emotion. They are also an individualcentric proximal cause in business outputs. Knowledge regarding the entrepreneurial behaviors is important for educators, students, and media and creative workers because they are usually the results of creation and innovation (Bird \& Schjoedt, 2009, p.352). Entrepreneurial behaviors can also be defined as a study on human behaviors involved in identifying and benefitting the opportunities by creating and developing new enterprises (Bird \& Schjoedt, p.353; Carsrud, Brannback, \& Brandt, 2009), and also in exploring and creating temporary opportunities in the appearing organizational process (Gartner, Carter \& Reynolds, 2010, p.99). The entrepreneurial behaviors are also admitted as supporting social changes and facilitating innovation within an established organization (Kuratko, Ireland, Covin, \& Hornsby, 2005, p.700). From the explanation, it can be concluded that entrepreneurial behavior is a function of direct interaction between an individual and his or her environment. An individual's behaviors are reflected in his or her attitudes when he or she would like to achieve certain objectives.

Table 1. The attitudes and the descriptions of entrepreneurship education value

\begin{tabular}{|c|c|}
\hline $\begin{array}{l}\text { Entrepreneurial } \\
\text { Behaviors }\end{array}$ & Description \\
\hline Independent & Not easily dependent on other people in accomplishing certain duties \\
\hline Creative & $\begin{array}{l}\text { Behaving and doing something in order to generate different ways or results from the } \\
\text { ones that have been possessed }\end{array}$ \\
\hline Risk-Taking & Able to do challenging jobs and courageous to take risks \\
\hline Orientation to action & Turning ideas into real actions \\
\hline Leading & Open to criticisms and suggestions, sociable, cooperative and directing other people \\
\hline Honest & Being a trustworthy person in terms of words, actions and jobs \\
\hline Disciplined & Obedient toward multiple regulations and requirements \\
\hline Hardworking & Performing actual efforts to accomplish tasks and overcome multiple drawbacks \\
\hline Cooperative & Able to establish relationships with the other people in performing actions and duties \\
\hline Innovative & Creative in solving problems and finding opportunities to improve and enrich life \\
\hline Responsible & Able and willing to perform the given obligations and duties \\
\hline Persistent & Not easily surrender in accomplishing an objective with multiple alternatives \\
\hline Communicative & Happy in talking, socializing and cooperate with other people \\
\hline
\end{tabular}

Source: Centre of Curriculum of Ministry of National Education (2010, pp.10-11) 


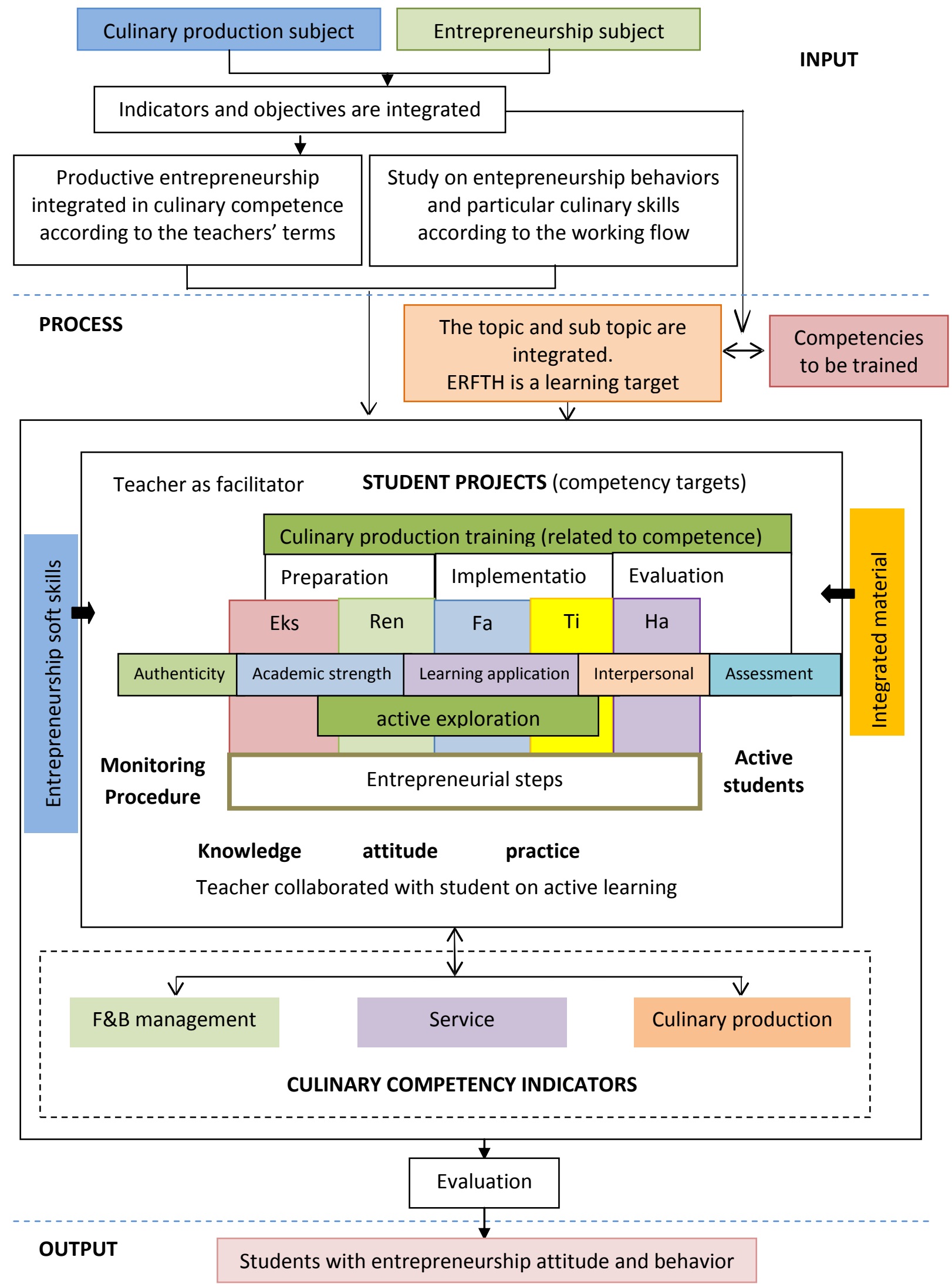

Figure 1. 'EkRenFaTiHa' production entrepreneurship learning model for the culinary vocational high school (Lastariwati, 2013) 
The entrepreneurial production learning model development for the culinary vocational high school will form entrepreneurial behaviors and it demands a learning condition that enables students to perform exploration, comprehension and implementation of the entrepreneurial values and independent attitude in a working situation. The situation serves as integrative media between hardskill and entrepreneurial skill. The mastery of entrepreneurial behaviors should be accompanied by feedback and support. A positive habituation will help to form positive habit and behavior.

The description of 'EkRenFaTiHa' production entrepreneurship teaching model for the culinary vocational high school can be seen in Figure 1.

\section{Method}

The study was conducted in 1 Sewon State Vocational High School and the subjects were the students of grade XI of Culinary Study Program who were taking continental cuisine class. A research and development $(\mathrm{R}$ $\&$ D) model was employed in the study. The main element of the model was the implementation of an integrated approach on entrepreneurship and production learning under project-based learning.

Plomp model (1997) was employed for the development of the entrepreneurial learning model in the culinary vocational high school. The general problem-solving model for the domain of education consisted of the following phases: Preliminary investigation; design; realization or construction; test, evaluation, and revision; and implementation.

The instruments used for data collection consisted of two different parts. The first was the instrument of students' entrepreneurial behaviors observation in which some trained enumerators reflected and observed the students' entrepreneurial behaviors during the production entrepreneurship learning process by means of the 'EkRenFaTiHa' model. The second was peer assessment which was representing the students' entrepreneurial behaviors assessment according to their colleagues during the learning process. Both instruments were tested in every meeting. The test was administered to measure the dynamic between the students' entrepreneurial attitudes and their entrepreneurial behaviors performed during the learning process by means of EkRenFaTiHa model.

\section{Findings and Discussions}

Table 2 presents the fluctuative changes in the students' entrepreneurial behaviors in each meeting. The students had different projects in the basic competence examination (the examination was made appropriate to the basic competence as the target of mastery). As a result, the fluctuative changes occur. It depends on the load of the projects that the students should finish. It is the most frequent trait. The 'independent' attitude (11\%) is the second, followed by 'responsible', 'honest', 'leading' and 'hardworking' (8\%). In the fourth place is 'innovative', 'disciplined', and 'cooperative' $(7 \%)$. In the fifth place, it is 'action-oriented' and 'persistent' attitude (5\%). 'Communicative' and 'risk-taking' attitude $(4 \%)$ are in the sixth place. The last is 'evaluative' and 'result-oriented' (3\%).

The students' courage to take risk and their 'communicative' attitude are low. Students admitted that they were shy and afraid of making mistakes (according to interviews). It is shown by their reason that they were not confident and afraid of selling their products.

Table 2. The frequency of entrepreneurial behaviors occurring in 1 Sewon State Vocational High School

\begin{tabular}{lc}
\hline \multicolumn{1}{c}{ Behaviors } & Mean \\
\hline Creative & 140.2 \\
Innovative & 75.6 \\
Independent & 120.6 \\
Responsible & 89 \\
Honest & 95.2 \\
Leading & 96.8 \\
Persistent & 57.2 \\
Disciplined & 83.6 \\
Cooperative & 76.6 \\
Action-Oriented & 58.8 \\
Hardworking & 87.8 \\
Communicative & 48.4 \\
Risk-Taking & 46.8 \\
Evaluative & 35 \\
Reflective & 28.8 \\
\hline
\end{tabular}

Source: Lastariwati (2013) 
Table 3 clearly shows that the highest achievement is found in the fourth meeting. In the fourth meeting, the students were able to run the project and to meet the target given by the teacher especially in terms of product sale.

The 'creative' attitude occurs dominantly with 701 times of occurence. The occurence of the attitude is mostly found in the action (35.38\%). Then, the 'innovative' attitude occurs 378 times. It occurs mostly in the action and exploration stages. On the other hand, 'independent' attitude occurs mostly in the action (47.60\%) and facilitation $(26.70 \%)$.

A similar situation is also found in the following attitudes, namely: 'responsibility' (445 times), 'honesty' (476 times), 'leading' (484 times), 'persistence' (286 times), 'discipline' (418 times), 'cooperative' (383 times), 'action-oriented' (294 times), 'hard-working' (439 times), 'communicativeness' (242 times) and 'risk-taking' (234 times). The 'evaluative' and 'reflective' attitudes occur frequently in the action and output (Table 3-4).

The changes of entrepreneurial behaviors in the action and output tended to be stable. However, the only significant improvement was found in the fifth meeting. The students' 'reflective' attitude occurs more frequently than 'evaluative' attitude.
The students' mastery of entrepreneurial behaviors was found in the peer assessment during the learning process. Peer assessment was an objective assessment conducted by the students' colleagues upon the mastery of entrepreneurial behaviors in a group. It was conducted at the end of the session.

The peer assessment on the entrepreneurial behaviors was performed five times in the continental culinary class. The changes of entrepreneurial behaviors occur in each meeting. Table 5 shows the data on the students' mastery of entrepreneurial behaviors in the implementation of production entrepreneurship learning model.

The changes of students' entrepreneurial behaviors occur due to different competencies that should be learned in each meeting (the project was prepared in accordance with the basic competence as the target of mastery). The changes depend on the load of the project that the students should run. The development of sudents' entrepreneurial behaviors in 1 Sewon State Vocational High School is positive (Table 6). The students' colleagues in the project were involved in order to evaluate the mastery of entrepreneurial behaviors that they possessed.

Table 3. The frequency of entrepreneurial behaviors occuring per entrepreneurial stage in 1 Sewon State Vocational High School

\begin{tabular}{|c|c|c|c|c|c|c|c|c|c|}
\hline & Creative & Innovative & Independent & Responsible & Honest & Leading & Persistent & Disciplined & Cooperativce \\
\hline $\bar{E}$ & 112 & 76 & 66 & 46 & 53 & 46 & 12 & 38 & 32 \\
\hline B & 151 & 43 & 35 & 43 & 39 & 47 & 29 & 42 & 18 \\
\hline $\mathrm{F}$ & 140 & 47 & 161 & 92 & 92 & 128 & 77 & 65 & 127 \\
\hline A & 248 & 173 & 287 & 216 & 239 & 210 & 137 & 231 & 169 \\
\hline $\mathrm{O}$ & 50 & 39 & 54 & 48 & 53 & 53 & 31 & 42 & 37 \\
\hline
\end{tabular}

Table 4. The frequency of entrepreneurial behaviors occurence per entrepreneurial stage in 1 Sewon State Vocational High School

\begin{tabular}{ccccccc}
\hline & Action-Oriented & Hardworking & Communicative & Risk-Taking & Evaluative & Reflective \\
\hline $\mathrm{E}$ & 18 & 34 & 13 & 26 & 9 & 11 \\
$\mathrm{~B}$ & 19 & 17 & 7 & 35 & 21 & 11 \\
$\mathrm{~F}$ & 85 & 97 & 56 & 38 & 28 & 13 \\
$\mathrm{~A}$ & 149 & 244 & 130 & 111 & 58 & 62 \\
$\mathrm{O}$ & 23 & 47 & 36 & 24 & 59 & 47 \\
\hline \multicolumn{5}{c}{ Note: E = exploration; B = business plan; F = facilitation; A = action; O = output }
\end{tabular}


The mastery of entrepreneurial behaviors based on the peer assessment in the 'Exploration' stage can be seen in Figure 2. In this stage, these behaviors were found: Responsible, honest, independent, innovative and creative. From these behaviors, it is found that 'responsible' attitude is the behavior the students master the most with the mean score of 3.04, while 'creative' attitude is mastered by the students in the second place with the mean score of 2.69.

Based on the five treatments observed, it is found that the mastery development in 'Exploration' stage is fluctuative. From Figure
2 , it is clear that entrepreneurial behaviors occur variously in each stage. In the 'Exploration' stage, 'responsible' attitude is the highest mastery, followed by 'honest', 'independent', 'innovative', and 'creative' attitudes.

From the peer assessment (Figure 3), it is found that the students' 'leading' attitude is a dominant aspect in the 'Business Plan' stage. The 'leading' attitude is a process of selfdirecting to give instruction or influence other people in a working group. During the treatment, the development showed a positive trend in each stage.

Table 5. The assessment on the students' entrepreneurial behaviors in continental culinary class

\begin{tabular}{|c|c|c|c|c|c|c|}
\hline Entrepreneurial Stage & Behaviors & Mean & St. Dev & Behaviors & Mean & St. Dev \\
\hline \multirow{3}{*}{ Exploration } & Creative & 2.69 & 0.11 & Honest & 2.82 & 0.11 \\
\hline & Innovative & 2.77 & 0.09 & Independent & 2.79 & 0.07 \\
\hline & Responsible & 3.04 & 0.05 & & & \\
\hline Business Plan & Leading & 2.79 & 0.05 & Disciplined & 2.93 & 0.08 \\
\hline \multirow{3}{*}{ Facilitation } & Persistent & 2.84 & 0.08 & Cooperative & 3.03 & 0.07 \\
\hline & Honest & 2.87 & 0.05 & & & \\
\hline & Responsible & 3.00 & 0.12 & & & \\
\hline \multirow{5}{*}{ Action } & Action Oriented & 2.71 & 0.06 & Cooperative & 2.98 & 0.04 \\
\hline & Discipline & 2.88 & 0.09 & Innovative & 2.83 & 0.1 \\
\hline & Responsible & 2.91 & 0.03 & Honest & 2.94 & 0.09 \\
\hline & Communicative & 3.01 & 0.12 & Hardworking & 2.72 & 0.09 \\
\hline & Risk-Taking & 2.79 & 0.09 & Independent & 2.84 & 0.08 \\
\hline Output & Evaluative & 1.49 & 0.16 & Reflective & 1.44 & 0.24 \\
\hline
\end{tabular}

Source: Lastariwati (2013)

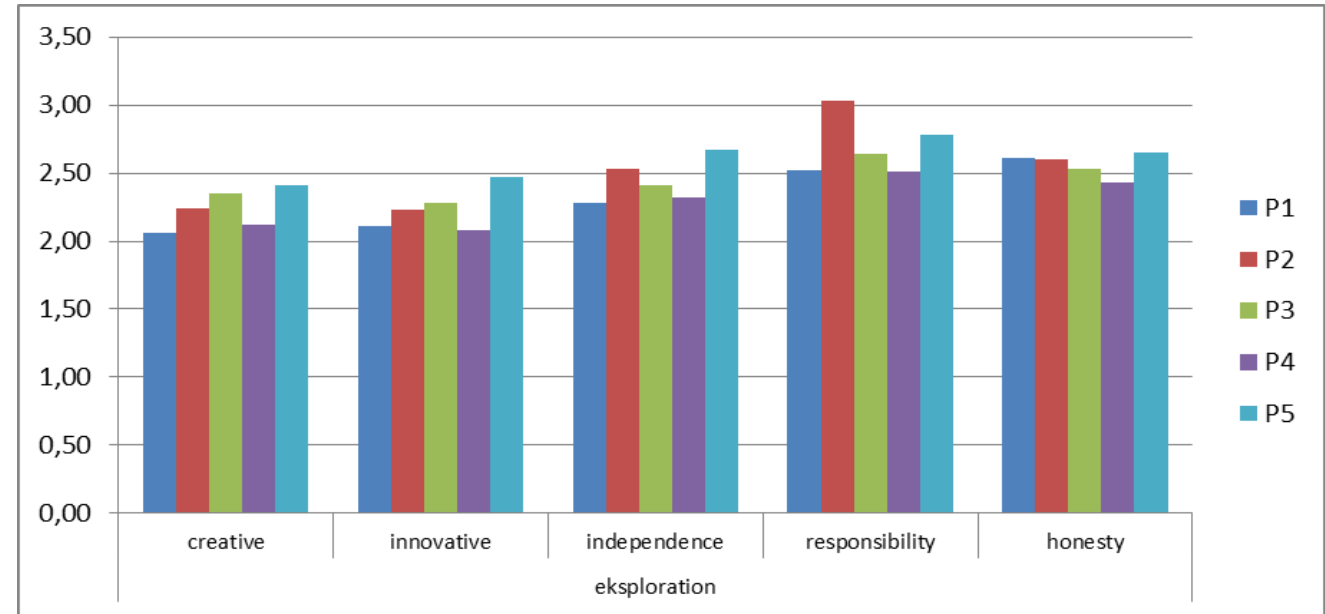

Figure 2. The occurence of entrepreneurial behaviors in the 'Exploration' stage (peer assessment) (Lastariwati, 2013) 
Figure 4 shows the profile of changes in the students' entrepreneurial behaviors. Although there is fluctuation in the 'Facilitation' stage, students' overall entrepreneurial behaviors show a positive trend in the development.

In the 'Action' stage, the entrepreneurial behaviors that the students mastered were: 'action-oriented' (2.71); 'disciplined' (2.88); 'cooperative' (2.98); 'innovative' (2.83); 'honest' (2.97); 'hard-working' (2.72); 'responsible' (2.91); 'communicative' (3.01); 'risk-taking' (2.79); and 'independent' (2.84). The changes in the entrepreneurial behaviors are varied and fluctuative.

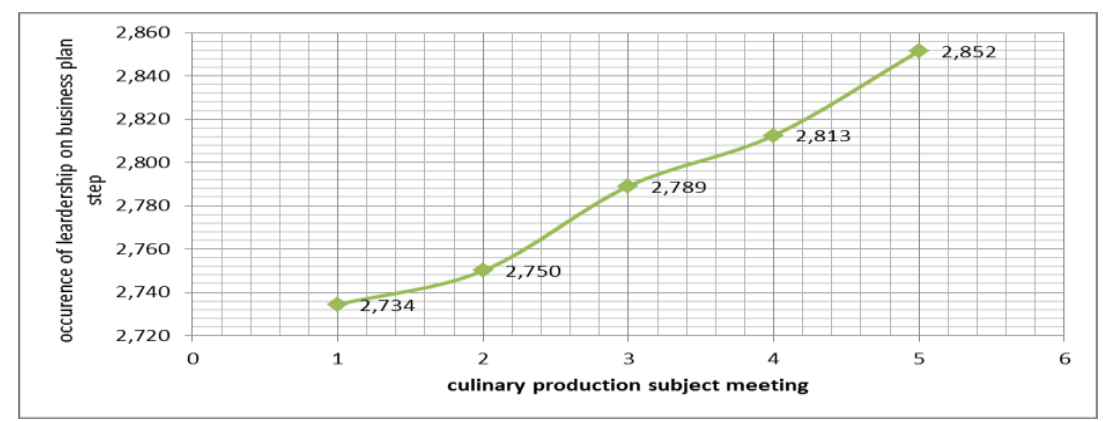

Figure 3. The occurence of entrepreneurial behaviors in the 'Business Plan' stage (peer assessment) (Lastariwati, 2013)

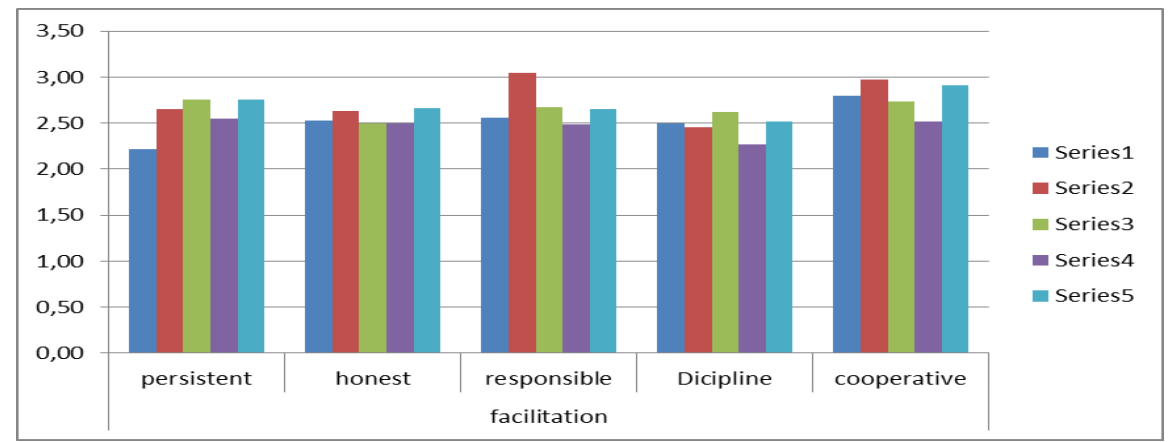

Figure 4. The occurence of entrepreneurial behaviors in the 'Facilitation' stage (peer assessment) (Lastariwati, 2013)

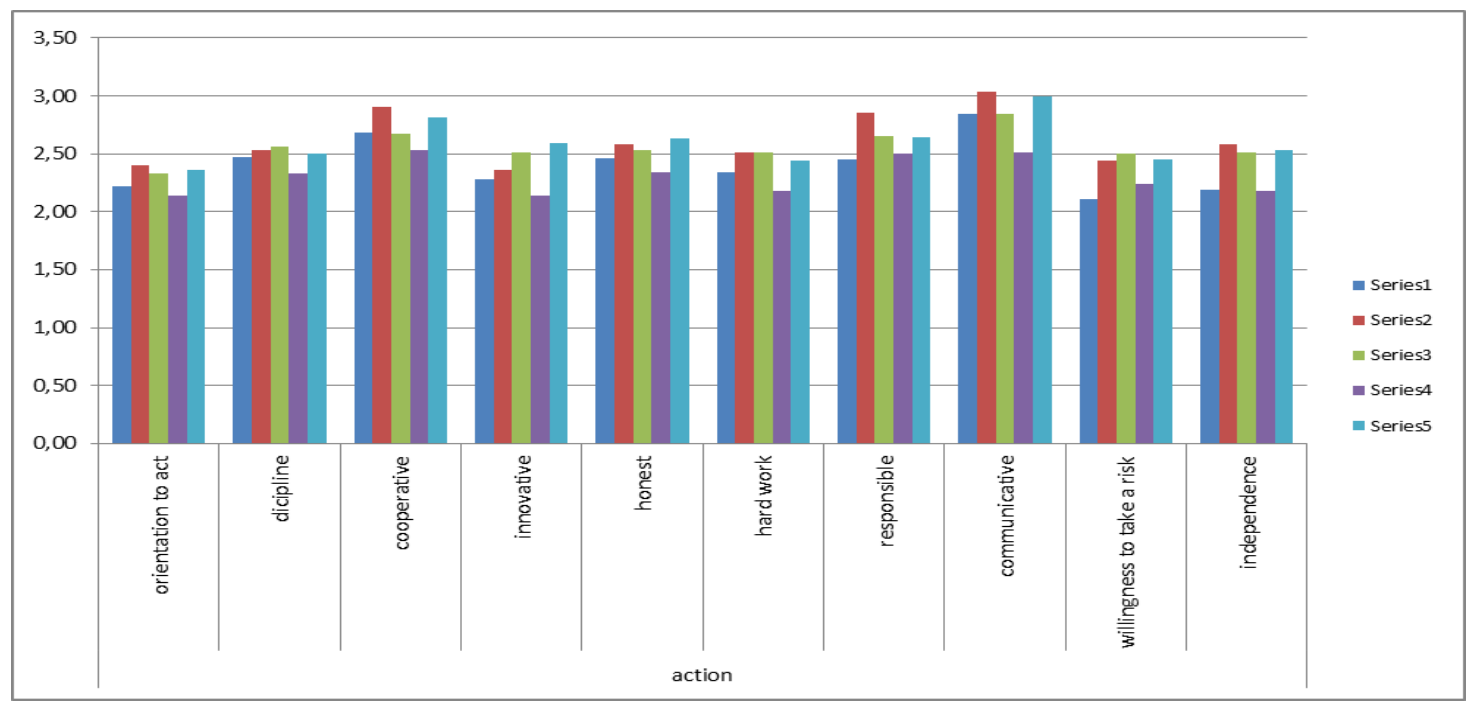

Figure 5. The occurence of entrepreneurial behaviors in the 'Action' stage (peer assessment) (Lastariwati, 2013) 
In the 'Result' stage, it is found that 'evaluative' and 'reflective' attitudes get the highest score (Figure 6). However, after the examination on the basic competencies, the students' learning targets and projects have met the requirements. The findings in the 'Output' stage was strengthened by the final assessment from the teachers.

In general, the mastery of entrepreneurial behaviors of the students of 1 Sewon State Vocational High School can be classified in several categories as presented in Table 6 .

The students' mastery of entrepreneurial behaviors was observed based on the self- evaluation sheet regarding the mastery of entrepreneurial behaviors in the daily activities. Subjectively, the students provided their opinion regarding the existence of the entrepreneurial behaviors and how they were applied in daily activities. For five times, they provided their opinion about the occurence of evenly-distributed entrepreneurial behaviors (Figure 7). The 'communicative' attitude is dominant with the mean score of $5.16 \pm 1.00$ (Table 7). Different from the results of evaluation, they argued that they had applied the 'evaluative' and 'reflective' attitude in their daily life.

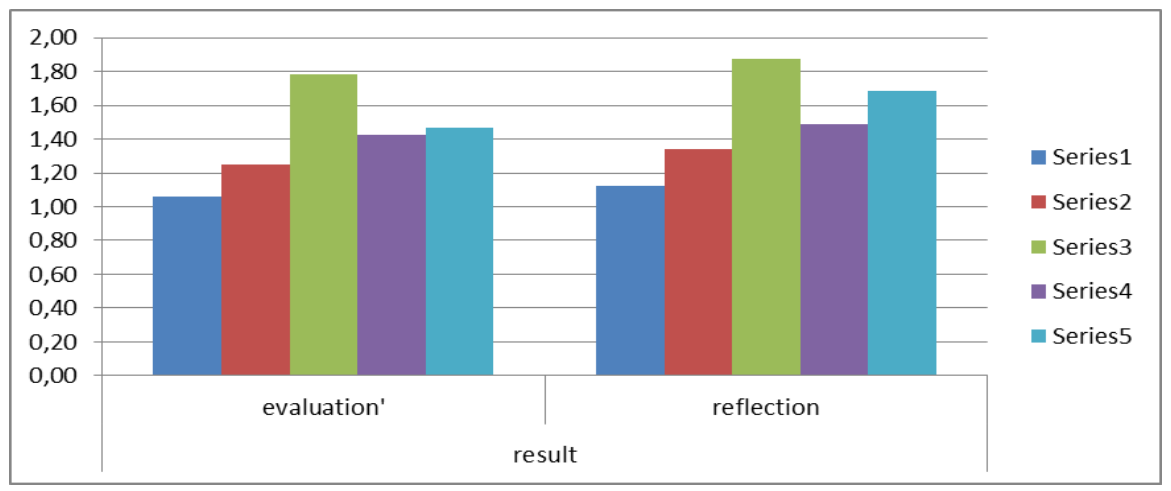

Figure 6. The occurence of entrepreneurial behaviors in the 'Result' stage (peer assessment) (Lastariwati, 2013)

Table 6. The classification of entrepreneurial behaviors mastery in 1 Sewon State Vocational High School

\begin{tabular}{cccc}
\hline No & Entrepreneurial Behavior Classifications & f & $\mathbf{\%}$ \\
\hline 1 & Poor & 2 & 1.3 \\
2 & Moderate & 22 & 13.8 \\
3 & Good & 117 & 73.1 \\
4 & Very Good & 19 & 11.9 \\
& Total & 160 & 100.0 \\
\hline
\end{tabular}

Source: Lastariwati (2013)

Table 7. The evaluation of the entrepreneurial behaviors of the students of 1 Sewon State Vocational High School

\begin{tabular}{lclc}
\hline \multicolumn{1}{c}{ Entrepreneurial Behaviors } & Mean & \multicolumn{1}{c}{ Entrepreneurial Behaviors } & Mean \\
\hline Creative & 4.24 & Disciplined & 4.53 \\
Innovative & 3.60 & Cooperative & 4.89 \\
Independent & 4.58 & Action-Oriented & 4.15 \\
Responsible & 4.44 & Hardworking & 4.87 \\
Honest & 4.87 & Communicative & 5.16 \\
Leading & 3.70 & Risk-Taking & 4.59 \\
Persistent & 4.10 & Reflective & 3.95 \\
Evaluative & 4.22 & Entrepreneurial Ability & 4.36 \\
Entrepreneurial Concept Drafting & 4.11 & Mean Score of Entrepreneurial Behaviors & 4.37 \\
\hline
\end{tabular}

Source: Lastariwati (2013) 
The entrepreneurial behaviors that have been reflected in the students of 1 Sewon State Vocational High School are 'communicative,' 'cooperative' and 'honest'. The students realized that performing 'honest', 'cooperative' and 'communicative' attitudes was important. The statement does not imply that other behaviors are not important; instead, all of the entrepreneurial behaviors overall complete each other in order to form a better person.

The mastery of entrepreneurial behaviors should be accompanied by feedback and support. A positive habituation would form a positive attitude.

In the implementation of the extended field test (the examination of basic competence), various cases of occurences from observation and peer assessment are found. Specifically, in 'Exploration' stage, the following entrepreneurial behaviors are found: 'Creative', 'innovative', 'independent', 'responsible' and 'honest'. Meanwhile, the entrepreneurial behavior found in the 'Business Plan' stage is 'leading'.

Then, in the 'Facilitation' stage, the following behaviors are found: 'Persistent', 'honest', 'responsible', 'disciplined' and 'cooperative'. Next, in the 'Action' stage, the following behaviors are found: 'Actionoriented', 'disciplined', 'cooperative', 'innovative', 'honest', 'hard-working', 'responsible', 'communicative', 'risk-taking' and 'independ- ent'. Eventually, the 'Output' stage is related to the 'evaluative' and 'reflective' attitudes.

For the mastery of entrepreneurial behavior during the examination of basic competence, the 'responsible' attitude ranks the first place. In other words, most of the students show 'responsible' attitude during the examination. Being responsible refers to have awareness in terms of accomplishing the given tasks or duties correctly and punctually. The students believe that every single hard work would be beneficial not only for themselves but also for other involved parties.

Meanwhile, the 'honest' attitude is in the second place. Being honest, during the examination, is an important element that should be included in the learning process. The reason is that all of the students should possess honesty within themselves. Furthermore, the 'cooperative' attitude is the third. Being cooperative refers to the ability of establishing relationship with other people in carrying out certain actions and duties. Being cooperative might also be a motivation for carrying out the given duties well and appropriately. In addition, the 'disciplined' attitude refers to any attitude that shows orderliness and obedience to multiple regulations and requirements. In the examination of basic competence, the students did the projects that had been decided and agreed with the teachers.

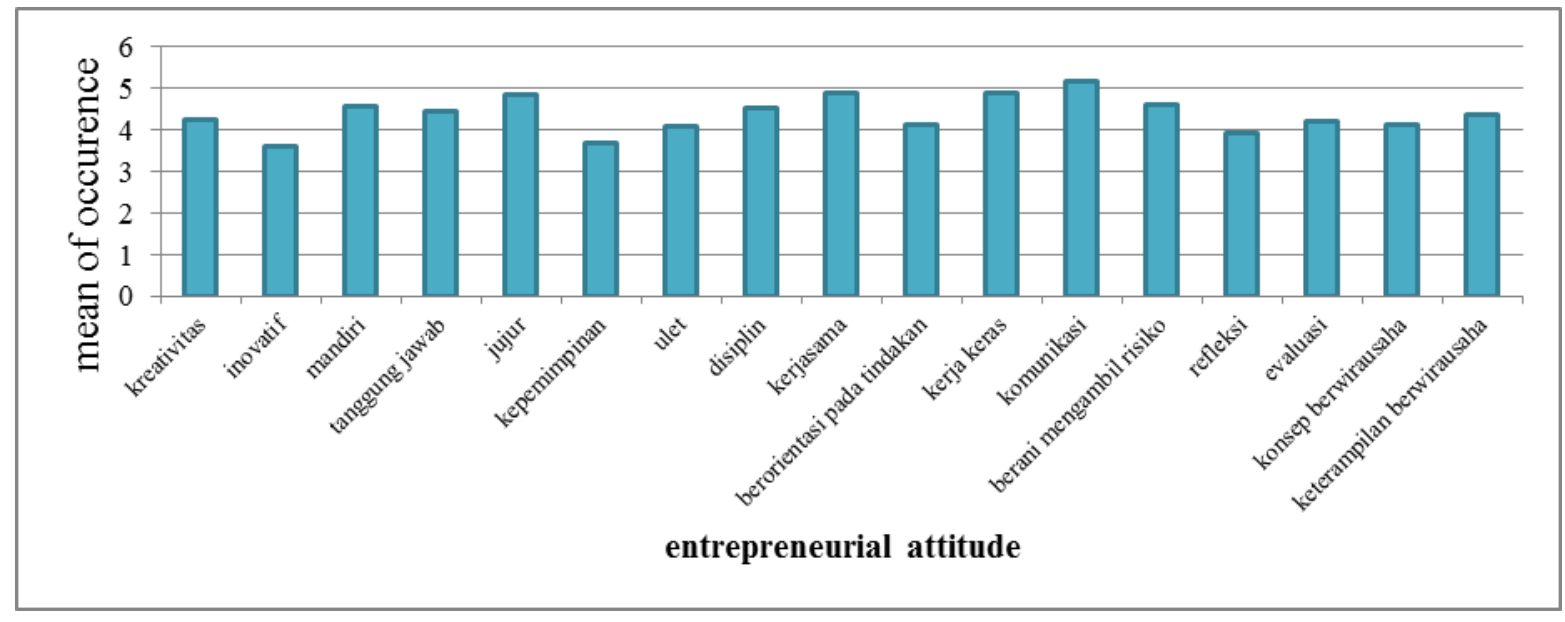

Figure 7. The evaluation of the entrepreneurial behaviors of the students of 1 Sewon State Vocational High School (Lastariwati, 2013) 
In relation to the other behaviors, the 'independent' attitude refers to not being easily dependent on other people in accomplishing the given tasks. Then, the 'innovative' attitude refers to the ability of employing creativity in order to solve problems and to find opportunities for improving and enriching life. Being creative describes the behaviors of generating something new with an added value. As a result, this something new might be admitted as an output of students' creation by the users. The communal creativity, in addition, occurs with improvement in each stage of the entrepreneurial process. Meanwhile, 'reflective' and 'evaluative' attitudes are the last behaviors in the list. After the examination of basic competence was accomplished, students' learning projects and targets were achieved. The 'Output' stage was strengthened by the final assessment from the teachers. The changes in entrepreneurial behaviors might also be given attention in each stage of the entrepreneurial process.

The mastery of students' entrepreneurial behaviors is strengthened by the students' self-assessment. It is a reflection of entrepreneurial behaviors applied by the students in their daily life. In relation to entrepreneurial behaviors, the behaviors mostly represented in 1 Sewon State Vocational High School are 'communicative', 'cooperative' and 'honest'.

\section{Conclusions and Suggestions}

Conclusions

The expanded field test for the productive entrepreneurial learning model implemented in the culinary vocational high school is concluded as follows. The expanded field test was performed in 1 Sewon State Vocational High School. The students' entrepreneurial behaviors in the implementation of the entrepreneurial process stages in 'EkRenFaTiHa' model integrated in the culinary production learning, namely in the Continental Cuisine class, were observed. The stages in the entrepreneurial process observed were: 'Exploration', 'Business Plan', 'Facilitation', 'Action' and 'Output'. In the implementation of preliminary investigation under the classical manner, the frequency of occurences of the entre- preneurial behaviors is repectively as follows (from the highest to the lowest): 'Responsible', 'innovative', 'honest', 'independent', 'creative', 'leading', 'persistent', 'disciplined', 'cooperative', 'risk-taking', 'independent' and 'communicative'. There has been actual improvement in the continuous repetition for each of the entrepreneurial behavior, and in general, the students' entrepreneurial behaviors might be classified as a good one.

\section{Suggestions}

Based on the research, it is recommended that: (1) 'EkRenFaTiHa' production entrepreneurship learning model can be implemented in actual manner in all production subjects within study programs under the culinary and the tourism vocational high schools as well as in the Fashion Study Program and the Beauty Study Program. Each of the projects might be customized according to the class conditions and the competences expected to be achieved. (2) It is also recommended that the implementation of 'EkRenFaTiHa' production entrepreneurship learning model be more effective if the model is supported by all of the school members. Thereby, the integration of entrepreneurship culture at schools might grow well.

\section{References}

Act of the Republic of Indonesia, No 20 Year 2003 about national education system (2003).

Bell, B.F. (1995). Children's science, contructivism and learning in science. Victoria: Deakin University Press.

Bird, B. \& Schjoedt, L. (2009). Entrepreneurial behavior: Its nature, scope, recent research, and agenda for future research. In A.L. Carsrud \& M. Brannback (Eds), Understanding the entrepreneurial mind: International studies in entrepreneurship, vol. 24 (pp. 327-358). Heidelberg, NY: Springer.

BNSP. (2006). Standar isi untuk satuan pendidikan dasar dan menengab: Standar kompetensi dan kompetensi dasar SMK/MAK [Content standard for primary and secondary 
educational units: Standard and basic competences]. Jakarta: Badan Nasional Sertifikasi Profesi (BNSP).

Carsrud, A., Brännback, M.J.E, \& Brandt, K. (2009). Motivations: The entrepreneurial mind and behavior. In A.L. Carsrud \& M. Brännback (Eds.), Understanding the entrepreneurial mind: Opening the black box (pp.141-166). Heidelberg, NY: Springer.

Centre of Curriculum of the Ministry of National Education. (2010). Bahan pelatihan penguatan metodologi pembelajaran berdasarkan nilai-nilai budaya untuk. membentuk daya saing dan karakter bangsa: Pengembangan pendidikan kewirausahaan [Training materials on strengthening learning methodology based on cultural values to form the nation's competence and character: Entrepreneurial education development]. Jakarta: Pusat Kurikulum Badan Penelitian dan Pengembangan Kementerian Pendidikan Nasional.

Ciputra (2009, November 3). Kewirausahaan harus menjadi karakter, kurikulum kewirausahaan diterapkan di sekolah tahun 2010 [Entrepreneurship must be a character, entrepreneurship curriculum will be applicable at schools in 2010]. Harian Kompas. Retrieved from http:/ / cetak.kompas.com/ read/xmll 2009/11/03/04323917/kewirausahaan.h arus..menjadi.karakter

Commission of the European Comminuties. (2006). Implementing the community lisbon programme: Fostering entrepreneurial mindsets through education and learning. Brussels: Communication from the Commission to the Council, the European Parliament, the European Economic \& Social Committee, \& the Committee of the Regions.

Consortium for Entrepreneurship Education. (2004). National content standards for entrepreneurship education. Retrieved on 12 November 2013 from http://www.entreed.org/standards too lkit/index.htm.
Directorate General for Enterprise \& Industry of European Commission. (2012). Effects and impact of entrepreneurship programmes in bigher education. Brussels: European Commission.

Directorate General of Educational Quality Improvement and Education Personnel. (2010). Pembelajaran berbasis PAIKEM (CTL, pembelajaran terpadu, dan pembelajaran tematik). Materi pelatiban penguatan-penguatan pengawas sekolah [Training materials on strengthening school supervisor]. Jakarta: Kementerian Pendidikan Nasional.

Directorate General of Secondary Education. (2011). Rencana strategis Direktorat Jenderal Pendidikan Menengah Kementerian Pendidikan dan Kebudayaan 2010-2014 [Strategic plans of the Directorate General of Secondar Education of the Ministry of Education and Culture 2010-2014]. Jakarta: Direktorat Jenderal Pendidikan Menengah, Kementerian Pendidikan dan Kebudayaan.

Ehmke, C., \& Akridge, J. (2005). The elements of a business plan: First steps for new entrepreneurs. Purdue Extension EC-735. West Lafayette, IN: AICCPurdue University.

European Commission Enterprise and Industry (ECEI). (2009). Best procedure project: Entrepreneurship in vocational education and training (final report of the expert group). Brussels: Enterprise \& Industry CG, European Commission.

Gartner, W.B., Carter, N.M., \& Reynolds, P.D. (2010). Entrepreneurial behavior: Firm organizing processes. In Z.J. Acs \& D.B. Audretsch (Eds.). Handbook of entrepreneurship research: An interdisciplinary survey and introduction (Vol. 5, part 2). New York, NY: Springer.

Global School Net. (2000). Introduction to networked project-based learning. Retrieved on 10 July 2011 from http://www.gsn. org/web/pbl/whatis.htm

Hawkins, K.L., \& Turla, P.A. (1993). Ujilah tingkah kecerdasan anda sebagai seorang 
wiraswatawan [Test your entrepreneurial attitudes]. Solo: Dabara.

Hisrich, R.D. \& Peters, M.P. (2002). Entrepreneurship $\left(5^{\text {th }}\right.$ ed.). Boston, MA: McGraw-Hill/Irwin.

Hisrich, R.D., Peters, M.P., \& Dean, A.S. (2005). Entrepreneurship (6 $\left.{ }^{\text {th }} \mathrm{ed}\right)$. New York, NY: McGraw-Hill/Irwin.

Kao, J.J. (1991). The entrepreneurial organization. New Jersey, NJ: Prentice Hall.

Kashmir. (2007). Kewirausahaan. Jakarta: Raja Grafindo Perkasa.

Kuehl, C., \& Lambing, P. (1999). Small business planning \& management ( $\left.3^{\text {rd }} \mathrm{Ed}\right)$. Oak Brook, IL: The Dryden Press.

Kuratko, D.F. \& Hodgetts, R.M. (1989). Entrepreneurship: A contemporary approach. San Diego, CA: Harcourt College.

Kuratko, D.F., Ireland, R.D., Covin, J.G., \& Hornsby, J.S. (2005). A model of middle-level managers' entrepreneurial behavior. Entrepreneurship Theory and Practice, 29(6), 699-716.

Lastariwati, B. (2013). Model pembelajaran kewirausabaan produktif EkRenFaTiHa untuk. Sekolah Menengah Kejuruan program studi pariwisata bidang keablian tata boga [Learning model of EkRenFaTiHa productive entrepreneurship for tourism program study in the expertise program of culinary in vocational high school] (Doctoral dissertation). Universitas Negeri Yogyakarta, Yogyakarta.

Lumpkin, G.T., Cogliser, C., \& Schneider, D. (2009). Understanding and measuring autonomy: An entrepreneurial orientation perspective. Entrepreneurship Theory and Practice, 33 (1), 47-69.

Macke, D. \& Markley, D. (2003). Readiness for entrepreneurship: Tools for energizing entrepreneurship. Center for Rural Entrepreneurship, No. 1. Retrieved from http://www.tvaed.com/pdf/readiness entreneurship.pdf

Ministry of Education and Culture. (2012). Pendidikan menengah universal (wajib belajar
12 tahun) [Universal secondary education (12-year compulsory education)]. Presented by the General Director of Secondary Education in a national discussion forum of the National Conference of Education and Culture in 2012 in Sawangan, Depok, Indonesia.

Ministry of National Education. (2010). Rencana pembangunan jangka menengah nasional kementerian pendidikan nasional 2010-2014 [National mid-term development planning of the ministry of national education in 2010-2014]. Jakarta: Kementerian Pendidikan Nasional.

Moerdiyanto. (2013). Peranan inkubator bisnis dalam pengembangan usaha mikro, kecil, dan menengah di Indonesia [The role of business incubator in developing micro, small, and medium enterprise in Indonesia]. Unpublished speech text of inauguration. Presented at the professor inauguration in Universitas Negeri Yogyakarta, Yogyakarta.

Muhadi, FX., \& Saptono, L. (2005). Jiwa kewirausahaan siswa SMK: Suatu survei pada tiga SMK negeri dan tujuh SMK swasta di DIY [Vocational high school (VHS) students' entrepreneurial spirit: A survey on three state VHSs and seven public VHSs in Yogyakarta]. Jurnal Widya Dharma, 16 (1), 15-28.

Noer, B.A, \& Wirjodirjo, B. (2007). Pola asuh orang tua yang membentuk jiwa wirausaha anak: Sebuah studi pada mahasiswa Teknik Industri ITS Surabaya [Parental education which forms children's entrepreneurial spirit: A study on the students of industrial engineering of ITS Surabaya]. Jurnal Ekonomi dan Manajemen, 8(2), 236-251.

Osterwalder, A. \& Pigneur, Y. (2010). Business model generation: A bandbook for visionaries, game changers, and challengers. Hoboken, NJ: John Wiley \& Sons.

Plomp, T. (1997). Educational design: Introduction. In T. Plomp. Educational and training system design: Introduction. Utrecht (the Netherlands): Lemma- Faculty of 
Educational Science and Technology, University of Twente, Netherland.

Purnomo. (1999). Modul kewirausabaan [Entrepreneurship module]. Jakarta: Universitas Terbuka.

Pusposutardjo, S. (1999). Pengembangan budaya kewirausahaan melalui matakuliah keablian [Developing entrepreneurial culture through expertise lecturing]. Paper presented at the Semiloka Wawasan Entrepreneurship. IKIP Yogyakarta, Yogyakarta.

Sanusi, A. (1994). Menelaab potensi perguruan tinggi untuk membina program kewirausahaan dan mengantar kehadiran pewirausaba muda [Analyzing higher education institutions potential to construct entrepreneurship program and bring out the presence of young entrepreneurs]. Paper presented at Seminar Kewirausahaan, Inkubator Bisnis Bandung, STMB-KADIN Jabar.

Sarbiran. (2002). Optimalisasi dan implementasi peran pendidikan kejuruan dalam era desentralisasi pendidikan [Optimalization and implementation of the role of vocation in educational decentralization era]. Speech presented at Dies Natalis XXXVIII UNY.
Soegoto, E.S. (2010). Entrepreneurship: Menjadi pebisnis ulung [Entrepreunership: Becoming skilled entrepreneurs] (revised ed.). Jakarta: Gramedia.

Suryana. (2003). Kewirausahaan: Pedoman praktis, kiat, dan proses menuju sukses [Entrepreneurship: A practical orientation, trick, and process to success]. Jakarta: Salemba Empat.

Wiklund, J. \& Shepherd, D. (2003). Knowledge-based resources, entrepreneurial orientation, and the performance of small and medium-sized businesses. Strategic Management Journal, 24, 13071314.

Winardi, J. (2004). Entrepreneur dan entrepreneurship [Entrepreneur and entrepreneurship]. Jakarta: Prenada Media.

Winarno, A. (2008). Pengembangan model pembelajaran internalisasi nilai-nilai kewirausahaan pada Sekolah Menengah Kejuruan di kota Malang [Developing entrepreneurial values internalization learning model to Vocational High Schools in Malang municipality]. Jurnal Ekonomi Bisnis, 14 (2), 124-131.

Zimmerer, W.T. (1996). Entrepreneurship and the new venture formation. New Jersey, NJ: Prentice Hall. 